\title{
Extraction and Characterization of chemical constituents present in Cuphea aequipetala and their properties.
}

Dhirendra Kumar Tiwari ${ }^{1}$, Ana Velia Coria-Tellez ${ }^{2}$, Dhananjay Tripathi ${ }^{3}$, María Olimpia Alonso-Perez ${ }^{4}$ and ANDREA DUBELZA NAVARRO-PÉREZ ${ }^{5}$

${ }^{1}$ CONACYT, Michoacan de Ocampo, Mexico, ${ }^{2}$ Laboratorio de Análisis y Diagnóstico del Patrimonio, El Colegio de Michoacán,, Michoacan de Ocampo, Mexico, ${ }^{3}$ ICMR- National Institute for Research in Environmental Health (NIREH) Bhopal, India, India, ${ }^{4}$ Laboratorio de Análisis y Diagnóstico del Patrimonio, El Colegio de Michoacán, La Piedad, CP. 59370, Michoacán, México, Michoacan de Ocampo, Mexico, ${ }^{5}$ UNIVERSIDAD AUTÓNOMA DE TAMAULIPAS, Tamaulipas, Mexico

\section{INTRODUCTION}

Mexico has a great importance in terms of medicinal plants due to its cultural and biological diversity while the studies of medicinal plants oriented towards quality control are scarce. One of the plants of American origin used in herbalism from Mexico is Cuphea aequipetala (C. aequipetala), currently this plant is on the list of species of ethnobotanical use in Mexico from the Herbal Extrapharmacopoeia. Taxonomically C.aequipetala is a perennial plant of herbaceous or subfruitful habit. It is a plant of wide distribution in Mexico, mainly in the center and south areas (popularly known as "hierba de cancer" but Márquez et al. (1999) y Martínez (1979) mentioned the other common name of the same as; alcáncer, apanchola, atlanchane, pegamosca, hierba de la calavera, mirto, trompetilla, ajam bomol, petalillo, hierba del ángel, guinda, cachancillo, alfilerillo, miel de abeja, motoye, pantillo, florecita roja, petalito, tatalito, siltic y zapotillo.

C.aequipetala has been used for the treatment of cancer, inflammation, pain, diarrhoea, fever, wounds and stomach infections. Today, many countries use plants to treat different maladies, such is the case of aqueos and organic extracts of $\mathrm{C}$. aequipetala have shown gastroprotective actions, cytotoxic activity against cancer cell lines, anti-lipase activity and antioxidant effects[4-7].

The investigation of medicinal plants using frontier technologies is now being reconsidered to be a feasible approach for discovering novel bioactive agents to solve widespread public health problems [7-9]. In this way increasing interest has been focused into the procedures for extract preparation and chemical constitutes characterizations because of their influence in the yield and modification of the activity of compounds. As a first approach in this study, the extracts obtained from C. aequipetala were analyzed by different methods. Being the MS-DART, FTIR, and Raman spectroscopy the techniques used for the chemical characterization of these.

\section{MATERIALS AND METHODS}

\subsection{Plant material}

The samples of C. aequipetala was obtained dry from a local vendor in La Piedad, Michoacan, who obtained it directly from indigenous people in the Purepecha area. The dried sample was placed in the 
oven at $45^{\circ} \mathrm{C}$ for 48 hours to remove the remaining moisture in the material. Subsequently, the humidity percentage was obtained, followed by this the material was subjected to a micromilling procedure in capsules with zirconium coating, to avoid contamination in the simples, these capsules were placed in a micromill equipment MM 400 Retsch, to obtain a particle size of $63 \mu \mathrm{m}$, this to homogenize and increase the effectiveness in the extraction process.

\subsection{Extraction methods}

The extracts of C. aequipetala were obteined by Soxhlet extraction method in four different solvents (ethanol, hexane, high-purity methanol and low purity methanol) for $4 \mathrm{~h}$. The solutions obtained in each case were concentrated by rotary evaporation and their at respective temperature and obtained extracts were collected and conserved for further analyses.

\subsection{Analytical techniques}

\section{a) Mass spectrometry DART-MS}

Direct analysis in real time mass spectroscopy (JEOL-AccuTOF JMS-T100LC (Jeol, Tokyo, Japan)) was applied to study of the present compounds in extracted samples where, Helium was used as the DART source gas for all analyses and polyethylene glicol 600 (PEG) was used for mass calibration.

b) Fourier transform infrarred spectroscopy coupled with attenuated total reflection (FTIR-ATR)

The Fourier transform infrared spectroscopy (FTIR, 110 Frontier MIR/NIR Perkin Elmer) was used to study the functional groups present in extracted samples between $4000-400 \mathrm{~cm}-1$ at resolution $4 \mathrm{~cm}-1,20$ scans were averaged in order to obtain a clear spectra of each sample.

\section{RESULTS}

The measurement of molecular compoundas obtained by AccuTOFTM-DART® (JEOL-AccuTOF JMST100LC (Jeol, Tokyo, Japan) where the obtained compounds are mentioned in Figure1.

The results shows that the possible extraction of compounds are only in selective solvents, like glucose was only possible in methanol based extraction both in high-pure as well low-pure, which is a very efficient source of energy in human body for daily uses as well on many specific diseases treatments as an energy source, while the ergosterol and epifriedelanol were found in hexane, while we could not be able to find any compound in ethanol based extraction.

The extract obtained using hexane showed two bands of high interests, one with a molecular weight of $396.65 \mathrm{~g} / \mathrm{mol}$ in the first band would be related to Ergosterol, a sterol and biological precursor of vitamin D, also contains the antitumor properties. Ergosterol peroxide is used to treat breast cancer. The second band was given by a molecular weight of $428.7 \mathrm{~g} / \mathrm{mol}$ related to Epifriedelanol, which has anticancer properties. 
The FTIR results (shown in Figure 2) from the different extracts obtained with ethanol, also pure and recirculated methanol in their corresponding spectra, showed a characteristic band $\sim 3400-3500 \mathrm{~cm}-1$ related to stretching vibration of $\mathrm{OH}$ groups. It should be noted that this band is not clearly seen in the extract obtained with hexanol, which can be attributed to the drying and pretreatment times of the sample.

In all spectra, a band is shown around $\sim 1709-1705 \mathrm{~cm}-1$, probably related to: stretching vibration of carboxyl groups, stretching of $\mathrm{C}=\mathrm{O}$ of flavonoids and lipids. The bands in the range $\sim 1456-1452 \mathrm{~cm}-1$, could be related to $\mathrm{CH} 3, \mathrm{CH} 2$, flavonoids and aromatic rings, where the vibrations would be the bending $(\delta)$ vibration of $\mathrm{C}-\mathrm{H}$ and the stretching vibration of aromatics.

\section{Compounds \\ Obtained}

\section{HC-SMP (ultra- pure methanol)}

\section{HC-SMR (low- purity methanol)}

HC-SME (high- HC-SH (high purity ethanol) purity hexane)
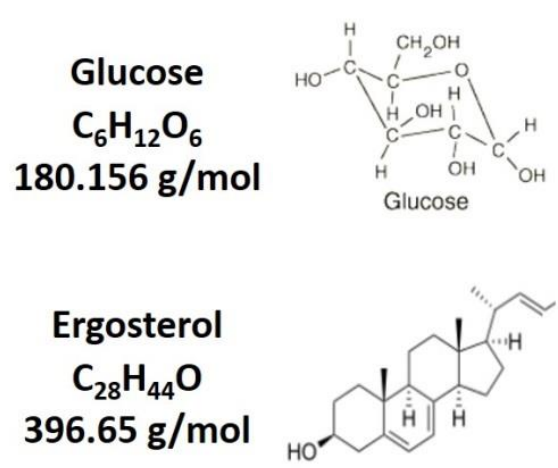
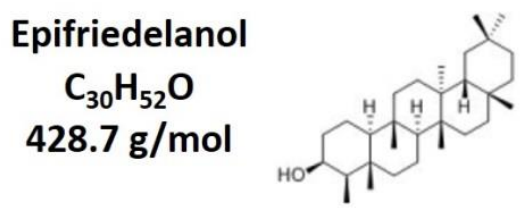

$x$

$X$

$x$




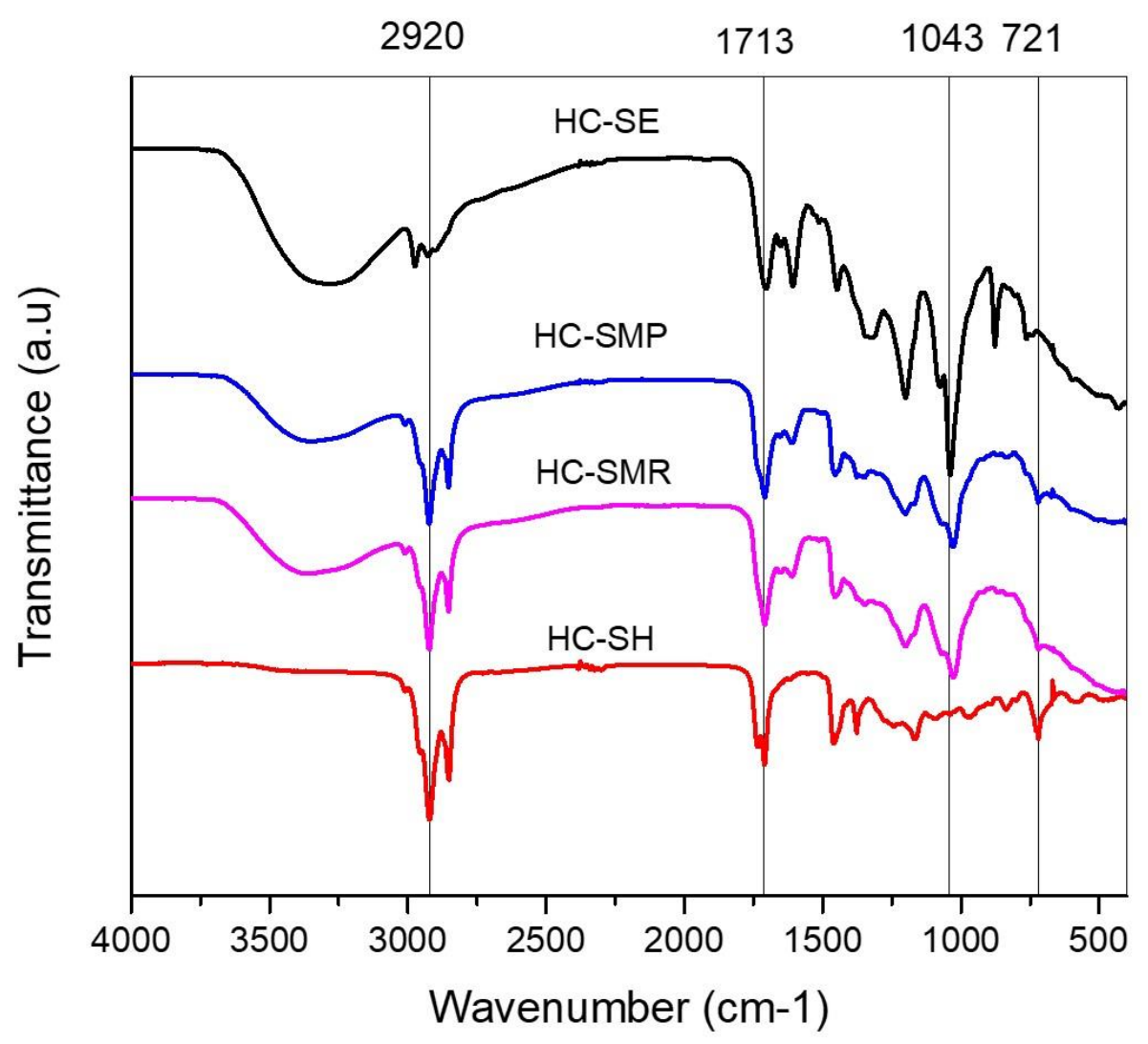

Figure 2. FTIR bands related to the C. aequipetala extract obtained By ethanol (HC-SE), hexane (HC-SH), high-pure methanol (HC-SMP), and low-purity methanol (HC-SMR) and their comparison.

\section{References}

1.Márquez, A. C., F. Lara O., B. Esquivel R. y R. Mata E. 1999. Plantas medicinales de México II. Composición, usos y actividad biológica. Universidad Nacional Autónoma de México. México, D. F.

2.Martínez, M., 1979. Catálogo de nombres vulgares y científicos de plantas mexicanas. Fondo de Cultura Económica. México, D.F

3. B.A. Cardenas-Sandoval, A.R. López-Laredo, B.P. Martínez-Bonfil, K. Bermúdez-Torres and G. TrejoTapia, Advances in the phytochemistry of Cuphea aequipetala, C. aequipetala var. hispida and C. lanceolata: Extraction and quantification of phenolic compounds and antioxidant activity, Rev. Mex. Ing. Quím vol.11 no.3 México dic. 2012

4. Aguilar-Rodríguez, S., Echeveste-Ramírez, N., López-Villafranco, M.E., Aguilar-Contreras, A., VegaÁvila, E., Reyes-Chilpa, R. 2012. Boletín Latinoamericano y dell Caribe de Plantas Medicinales y Aromáticas 11 (4): 316-330.

5. Cos, P., Vlietnick,A.R.,VandenBerghe,D.,Maes,L.,2006. Anti-infective potential of natural products:how to develop a stronger in vito"proof-of concept".J.Eth- nopharmacol. 106,290-302. 6. González, A.G., Valencia, E., Siverio-Expósito, T., Bermejo-Barrera, J., Gupta, M.P. 1994. Chemical Components of Cuphea Species. Carthagenol: A New Triterpene from C. carthagenensis. Planta Med. Letters 60.

7.Harvey,A.L.,Edrada-Ebel,R.,Quinn,R.J.,2015.There-emergence of natural products for drug Discovery in the genomics era.Nat.Rev.Drug.Discov.14, 111-129. 
8.Nunes-Oliveira, R., Cordeiro-Mancini, M., Cabral Salles-Oliveira, F., Marques-Passos, T., Quilty, B., Silva Moreira-Thiré, R.M., McGuinness, G.B. 2016. g. Revista Materia V.21, N.03: 767-779.

9.Sharma, A., Flores-Vallejo, R., Cardoso-Taketa, A., Villarreal, M.L. 2016. Review: Antibacterial activities of medicinal plants used in Mexican traditional medicine. Journal of Ethnopharmacology 208: 264-329. 